\title{
Opportunities and Constraints in Financing SMEs
}

\author{
Lăcătuş Viorel Dorin ${ }^{1}$, Văidean Viorela-Ligia ${ }^{2}$
}

\begin{abstract}
:
The enterprise is the most important component of the economy and of the society as well. The paper studies the weights of SME sector in different countries, focusing on topical operational issues for financing SMEs. In Romania, these are mainly shareholders' credits; own resources, loans, European Union or EBRD funds, etc. Some analysts consider that the growth of SMEs is impeded by an insufficient supply of capital.

In Romania as in other states, the public authorities have interceded to fill this equity gap by increasing the supply of funds. Furthermore, managerial opinions concerning the obstacles faced by their firms reveal some potential growth factors for SMEs: the size of loans, the amount of reinvested profit, well-educated human resources and technical assistance, all critical to the success of SME's in exploiting, indeed surviving, the rapid globalization of markets.
\end{abstract}

\footnotetext{
${ }^{1}$ Assistant Professor Babeş-Bolyai University, Cluj-Napoca, Romania Faculty of Economics and Business Administration, Finance Department

${ }^{2}$ PhD student, Babeş-Bolyai University, Cluj-Napoca, Romania Faculty of Economics and Business Administration, Finance Department
} 


\section{Introduction}

The enterprise sector is an important segment of the whole national and world economy and that is why its development is being stimulated and supported in many different ways. Small and medium sized enterprises are, according to theory, a permanent source of innovations, creativity and new jobs. According to empirical researches, the majority of innovations in economy occur in small sized enterprises.

There are permanent problems with financing own investment projects for this kind of enterprises and there also are problems about the choice of relevant models for financing and overcoming the financial barriers. Small sized enterprises' financing problem is particularly expressed in transition economies where financing techniques have not reached the satisfactory level of implementation and development yet.

An enterprise is considered to be a SME (micro, small or middle sized enterprises) if it fulfils all the conditions regarding the number of employees, the turnover, the maximum capital and the representing criteria of its social parts. Characteristics of the above mentioned enterprises and their financing models also vary with their development and growth and with their different historical, economic and cultural conditions.

The entrepreneurs represent one of the main pillars of the market economy. Their strong impact upon the status and the evolution of any economy results from the following aspects:

-they usually have the initiative for creating SMEs, the most dynamic component of the economic system;

-they are the ones that usually transform SMEs into larger and stronger companies;

-they have a major direct and indirect impact upon remodelling the economic environment, especially in Eastern Europe, where they've created the market economy.

The other pillars or main actors of the market economy are the professional managers, the bankers, the risk investors and the brokers. Together with the entrepreneurs, they form the human force vector that establishes a performing economy within a country. That is why they must be treated as an inestimable-value national resource, that has to be encouraged and whose capacity must be used to the highest degree in order to amplify the performances of the national economy.

\section{Aspects Regarding the Capital Structure of a SME}

All the enterprises, regardless their size, their maturity degree, their geographical place and their activity field, need capital in order to launch and to maintain 
themselves and further on to develop their activities. The capital may be attracted either through loans or through equity and may take the form of varied financial instruments. The loan instruments used by SMEs cover especially term or current bank loans, credit lines for exploiting activities, credit cards, leasing, supplier's credit contracts and government guaranteed loans (Břečková and Havlíček, 2013; Havlíček et al., 2013).

The capital investments as SME shares may be different categories of enterprise shares, i.e. a personal investment made by the investor, risk capital placements and, for the enterprises listed on the stock exchange, to buy state emitted stocks.

Nevertheless, the undistributed profits of an enterprise may be reinvested in the enterprise. A new enterprise needs initial capital in order to start its activity, to buy materials and basic assets, circulating capital enough for assuring the functionality of current activities and "expansion capital" for acceding to other resources that would be invested in new technologies and in other business opportunities, as the enterprise develops and becomes more profitable (Thalassinos and Pociovalisteanu, 2009).

Analyzing their maturity degree and the sector they develop their activity into, the SMEs choose the financial instruments that best correspond with the investors' desires. The majority of enterprises choose to combine financing through lent capital with financing through equity (Liapis et al., 2013). As a result, their financial structure will vary in time depending of the short term and long term financial needs of the enterprise.

Moreover, the enterprises performing within economical sectors where the products' operating cycles are long or the yield of the invested capital is good mostly use equity capital financing when realizing the products and, particularly, funds coming from business angels and investors in capital risk. The mature fields of activity risk not to attract the investors and their capital because their potential yields are lower and are susceptible to appeal to classical lend instruments.

\section{The Capital Offer}

There are diverse factors that influence an investor's decision for investing in a SME. Usually, the capital offer is directly influenced by the relative risk and the yield of the invested capital, considering the economic conjuncture, the possibility for more profitable investments and nevertheless, the transaction costs associated with the investment.

For the investments made by an investor for purchasing assets, the geographical placement is often another factor that influences the capital offer because the investors prefer to be as close as possible to their investment. 
In order to evaluate the relative risk of an investment, the investor will consider the profitability of the enterprise, its history for credit and the given guarantees, as well as of the entrepreneurs' knowledge regarding the business field.

These are not valid for a new enterprise, that does not have own history. In this case, the investor may attenuate the insolvency risk for the SME's investment by a couple of measures, like getting personal guarantees from the entrepreneur and the personal asset cession for the creditor, in case of bankruptcy.

We further present some factors that influence the capital offer for SMEs:

-the general economic conjuncture;

-the tendencies for institutional investments and commercial strategies;

-the activity field of the enterprise that benefits from the investment;

-the size, the maturity degree and the net assets' value of the enterprise which benefits from the investment.

It is important to underline the fact that all the above mentioned factors that influence the offer are common for all SMEs that want to get capital.

\section{Possibilities of Financing SMEs}

A major concern must be laid upon the opportunities of financing this sector, especially because it obtained the higher net profits referred to the total turnover. The main problem faced by SME's when trying to obtain funding is that of uncertainty, caused by the following facts:

- SME's rarely have a long history or successful track record that potential investors can rely on in making an investment;

- larger companies (particularly those quoted on a stock exchange) are required to prepare and publish much more detailed financial information - which can actually assist the finance-raising process;

- banks perceive them as having a greater credit risk.

The financing problem becomes extremely important when a company starts growing rapidly, for example when contemplating investment in capital equipment or an acquisition. The constant need for sources of finances can be balanced internally ("owner financing"). But few growing companies are able to finance their expansion plans from cash flow alone. They will therefore need to consider raising finance from other external sources. In addition, managers who are looking to buy-in to a business ("management buy-in" or "MBI") or buy-out ("management buy-out" or "MBO") a business from its owners may not have the resources to acquire the company. They will need to raise finance to achieve their objectives.

There are a number of potential sources of finance to meet the needs of small and growing businesses: 
- Existing shareholders and directors funds ("owner financing")

- Merchant banks (medium to longer term loans)

- Trade credit

- $\quad$ Hire purchase and leasing

- Government subsidies

- Funds from international organisms

- Factoring and invoice discounting

- Overdraft financing

- Equity finance

Most of them are already present on the Romanian market. In particular, a lot of international organisms participate in financing Romania.

\section{The Evolution of SME Sector}

Statistics from most European countries show that SMEs prevail over the economy, representing over $99 \%$ of the total firms and having important weights in GDP and employment growth. SMEs have an essential contribution to social and economic development, generating important percentages of the GDP: $45,76 \%$ in France, $60,17 \%$ in Germany, $71,38 \%$ in Italy and $82,87 \%$ in Greece, as stated in recent studies of the Romanian National Agency for SMEs. The average percentage of SMEs contribution to GDP in the European Union-15 is 51,69\% .

Table 1. The weight of SMEs in economy

\begin{tabular}{|l|l|l|l|}
\hline The country & $\begin{array}{l}\text { \% SMEs to total } \\
\text { enterprises }\end{array}$ & \%MEs to GDP & $\begin{array}{l}\text { \%SMEs in providing } \\
\text { workplaces }\end{array}$ \\
\hline Austria & 99,60 & 50,86 & 65,50 \\
\hline Belgium & 99,80 & 64,49 & 68,90 \\
\hline Denmark & 99,70 & 58,75 & 68,74 \\
\hline Finland & 99,75 & 44,33 & 59,15 \\
\hline France & 99,79 & 45,76 & 66,86 \\
\hline Germany & 99,63 & 60,17 & 59,85 \\
\hline Great Britain & 99,80 & 38,40 & 55,30 \\
\hline Greece & 99,95 & 82,87 & 86,68 \\
\hline Ireland & 99,59 & 33,02 & 69,59 \\
\hline Italy & 99,94 & 71,38 & 80,34 \\
\hline Luxemburg & 99,62 & 74,20 & 72,32 \\
\hline Holland & 99,56 & 56,06 & 62,47 \\
\hline Portugal & 99,87 & 66,80 & 78,87 \\
\hline Spain & 99,89 & 55,30 & 79,45 \\
\hline Sweden & 99,67 & 51,51 & 61,37 \\
\hline
\end{tabular}

Source: Authors' calculations

Furthermore, SMEs remunerate important percentages of the employable population of different countries: 66,86\% in France, 59,85\% in Germany, 80,34\% in Italy and $86,68 \%$ in Greece. The average percentage all over the EU-15 is approximately 
$66,32 \%$. The conclusion drawn at a closer look over these figures is that SMEs offer jobs for the great majority of the population, generating many working places, further leading to socio-economic fulfilment for the people and peoples, and generating the main income sources of the state budget.

\section{Particularities of Romanian SME's Activity}

In Romania, the SME sector is below the development it has in the EU-15: there exist 52 SMEs at a thousand inhabitants whereas in Romania this indicator is only 14 SMEs/ 1000 inhabitants. Furthermore, a low rate for setting up new companies is recorded. The European society believes in a strong SME sector, not only because of the economic advantages of having more production units to react quickly on a dynamic market, to be capable of introducing new technologies and to personalize their products and services offer, but because they also represent a guarantee for future's democracy. By locally promoting the access to information, to services and to financing for Romanian SMEs, this drawback would be outran, especially as new opportunities for growth, larger than challenges, would appear in the context of adhesion to the EU.

An increasing trend is noticed on the weights of the Romanian private sector in forming the GDP: the percentage of $65,6 \%$ recorded at the beginning of the millennium grew at $75 \%$ in 2007 . In the last years, foreign investments directly in SMEs mostly came from Italy (17\%), Netherlands (15\%) and Greece (10\%).

SMEs distribution on activities sectors reveals a high contribution in the services sector, followed by the agricultural sector and constructions' sector. With respect to services, trade and tourism were of great success. Still, the turnover in the services sector is three times larger that the one in the industrial sector and about thirty times larger than the total in constructions or agriculture.

\section{Conclusions}

A key consideration in choosing the source of new business finance is to strike a balance between equity and debt to ensure the funding structure suits the business. The overall objective in raising finance for a company is to avoid exposing the business to excessive high borrowings, but without unnecessarily diluting the share capital. This will ensure that the financial risk of the company is kept at an optimal level.

SMEs have certain "congenital weaknesses" that need to be acknowledged and fought back, this being essential for the economy and for the population as well. These are:

-the few incorporable resources they pertain and the reduced reserve they have;

-the firm's existence usually depends of a single person, the entrepreneur; 
-the frequent decreased technical development, as compared to large enterprises;

-"volatile" stability, due to the above presented traits.

To conclude with, we could sum up some recommendations for embittering SMEs' access to financing, a constraint factor. Its highly important to act upon:

- $\quad$ step by step constituting a system of guaranteed and co-guaranteed funds on national and regional level, for financing SMEs;

- reducing the fees and guarantees required by banks when approving a loan and simplifying the procedures of obtaining a loan

- $\quad$ subsidizing the interest rates in loans for SMEs;

- elaborating a national programme for teaching managers how to access structured funds, based on a public-private partnership;

- $\quad$ setting an investment bank for SMEs.

\section{Bibliography}

Břečková, P. and Havlíček, K. (2013). Leaders Management and Personnel Controlling in SMEs. European Research Studies Journal, 16 (4), Special Issue on SMEs.

Commission of the European Communities, SME Envoy Report 2005, www.europa.eu.int/comm/enterprise/entrepreneurship/sme_envoy

Eurobarometer, SME Access to Finance, www.ec.europa.eu/enterprise Opinions upon SMEs, the booklet from www.cnipmmr.ro

Havlíček, K., Thalassinos I.E. and Berezkinova, L. (2013). Innovation Management and Controlling in SMEs. European Research Studies Journal, 16(4), 57-70, Special Issue on SMEs.

Liapis, K., Rovolis, A., Galanos, C. and Thalassinos, I.E. (2013). The Clusters of Economic Similarities between EU Countries: A View Under Recent Financial and Debt Crisis. European Research Studies Journal, 16(1), 41-66.

Romanian SMEs' White Chart, Olimp Publishing House, Bucharest 2006 www.animmc.ro

Thalassinos, I.E. and Pociovalisteanu, M-D. (2009). The Structural Funds and the Economic and Social Cohesion Process. Annals-Economy Series 1, 313-330. 